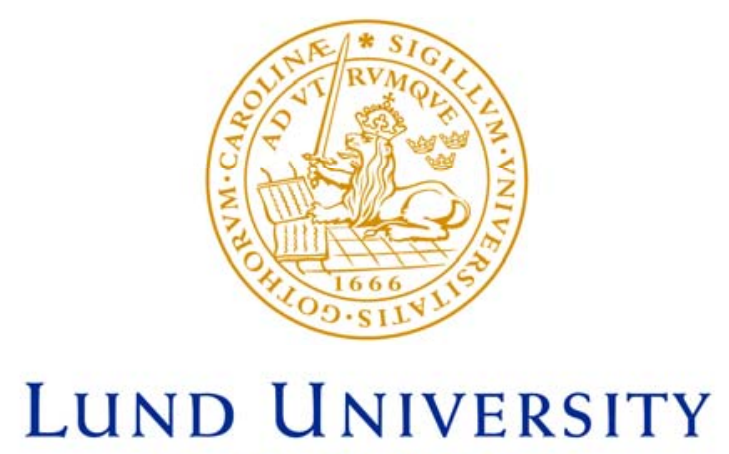

Faculty of Medicine

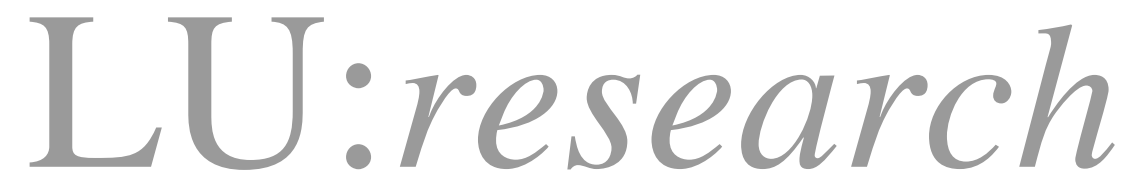

Institutional Repository of Lund University

This is an author produced version of a paper published in The Annals of Thoracic Surgery. This paper has been peerreviewed but does not include the final publisher proofcorrections or journal pagination.

Citation for the published paper:

Steen, Stig and Ingemansson, Richard and Eriksson, Leif and Pierre, Leif and Algotsson, Lars and Wierup, Per and Liao, Qiuming and Eyjolfsson, Atli and Gustafsson, Ronny and Sjöberg, Trygve.

"First human transplantation of a nonacceptable donor

lung after reconditioning ex vivo"

Ann Thorac Surg, 2007, Vol: 83, Issue: 6, pp. 2191-4.

http://dx.doi.org/10.1016/j.athoracsur.2007.01.033

Access to the published version may

require journal subscription.

Published with permission from: Elsevier 


\section{FIRST HUMAN TRANSPLANTATION OF A NONACCEPTABLE DONOR LUNG AFTER} RECONDITIONING EX VIVO

Stig Steen ${ }^{1} \mathrm{MD}, \mathrm{PhD}$, Richard Ingemansson ${ }^{1} \mathrm{MD}, \mathrm{PhD}$, Leif Eriksson ${ }^{1} \mathrm{MD}, \mathrm{PhD}$, Leif Pierre ${ }^{1}$ CPP, Lars Algotsson ${ }^{1}$, Per Wierup ${ }^{2}$ MD, PhD, Qiuming Liao ${ }^{1}$ MD, Atli Eyjolfsson ${ }^{1} \mathrm{MD}$, Ronny Gustafsson ${ }^{1} \mathrm{MD}, \mathrm{PhD}$ and Trygve Sjöberg ${ }^{1} \mathrm{PhD}$

\footnotetext{
${ }^{1}$ Department of Cardiothoracic Surgery, Heart and Lung Division, Lund University Hospital, SE 22185 Lund, Sweden
} and ${ }^{2}$ Department of Cardiothoracic Surgery, Skejby Hospital, Aarhus University, 8220 Aarhus, Denmark

Keywords: Lung evaluation, nonacceptable donor lungs, reconditioning, Steen Solution Word count: 3146

Correspondence: $\quad$ Stig Steen, Dept of Cardiothoracic Surgery

Heart and Lung Division, Lund University Hospital

SE-221 85 LUND, SWEDEN

Phone: +46-46-249999, Fax +46-46-249901

E-mail: stig.steen@,med.lu.se 


\section{ABSTRACT}

Background: A majority of lungs from brain dead donors are not accepted for transplantation. We have developed a method to evaluate and recondition nonacceptable donor lungs ex vivo. This paper describes the method and the first patient transplanted with a reconditioned lung from a donor deemed by all transplantation centers in the Nordic countries to have nonacceptable lungs for transplantation.

Method: A 19-year-old man was declared brain-dead after being hit by a car. He had continual bleeding into the trachea. Chest X-ray showed severe contusion of the right lung and some contusion of the left lower lung. The arterial oxygen tension was $9 \mathrm{kPa}(67.5 \mathrm{mmHg})$ on $\mathrm{FiO}_{2}=$ 0.7 with a PEEP of $5 \mathrm{cmH}_{2} \mathrm{O}$. All lung transplantation centers in the Nordic countries were contacted; all deemed the lungs to be nonacceptable for transplantation. The left lung was reconditioned ex vivo and was successfully transplanted into a 70 years old man with COPD, 17 hours after the donor operation.

Results: During the 6 postoperative weeks the patient was under our observation he was in a very good condition, had no rejection and his chest X-ray was normal. At the 3 months control CT thorax showed a normal transplanted left lung and in transbronchial biopsies there were no sign of rejection. Eleven months after transplantation he got acute sepsis and died.

Conclusion: The left lung from a heart-beating donor deemed to have nonacceptable lungs for donation was successfully reconditioned ex vivo and transplanted into a 70-year-old man with COPD.

Abstract word count: 250 


\section{INTRODUCTION}

A majority of lungs from brain dead donors are not accepted for transplantation. We have developed a method to evaluate and recondition nonacceptable donor lungs ex vivo. This paper describes the method and the first patient transplanted with a reconditioned lung from a donor deemed by all transplantation centers in the Nordic countries to have nonacceptable lungs for transplantation.

\section{MATERIAL AND METHODS}

\section{The donor}

In May 22, 2005 a 19-year-old man (heigt: $190 \mathrm{~cm}$, body weight: $70 \mathrm{~kg}$, blood group: O, Rhesus negative) was hit on his right side by a car when bicycling without a helmet. He was immediately admitted to a nearby hospital with severe head and thoracic injuries and in a deep coma. The victim was intubated and blood suctioned from the endotracheal tube. Chest X-ray showed bilateral lung contusions, most excessive on the right side. Brain CT showed severe contusion, and after a few hours brain death was declared and permission for organ donation obtained. The arterial oxygen tension had been low at all measurements. The last value measured before the organ donation operation started was only $9 \mathrm{kPa}(67.5 \mathrm{mmHg})$ despite an inspired oxygen fraction $\left(\mathrm{FiO}_{2}\right)$ of 0.7 . The deceased was not considered a potential lung donor, due to poor blood gases, combined with the severe lung contusion seen on the X-ray and the blood in the trachea. However, one of the doctors in contact with the donor knew of the research program at Lund University Hospital on nonacceptable donor lungs and contacted us. The responsible doctor in the donor hospital then decided to first offer the lungs to Scandia Transplant (The organ allocation organization for the Scandinavian countries). They were 
deemed to be nonacceptable by all the lung transplantation centers (Copenhagen, Gothenburg, Oslo and Helsinki). After this we were offered the lungs. At $5 \mathrm{pm}$, the heart, liver and kidneys were harvested by other teams and our team preserved the lungs with a cold pulmonary artery perfusion (pulmonary arterial pressure $\leq 15 \mathrm{mmHg}$ ) with 2 L Perfadex ${ }^{\circledR}$ (Vitrolife $A B$, Kungsbacka, Sweden) with added calcium chloride $0.3 \mathrm{mmol} / \mathrm{L}$, nitroglycerin $5 \mathrm{mg} / \mathrm{L}$ and Addex-THAM $1 \mathrm{mmol} / \mathrm{L}$. The lungs were placed in a plastic bag and submerged in Perfadex and transported to Lund, Sweden, where they arrived at $7 \mathrm{pm}, 2$ hours after the preservation procedure. Blood samples from the donor were delivered to our blood bank, and 4 units of erythrocyte concentrate (leukocyte filtered and irradiated) were ordered.

\section{Macroscopic evaluation of the donor lungs}

The right lung was severely injured with intraparenchymal hematomae (Fig 1). Small bleeding spots could be observed also in the lower lobe of the left lung. When the trachea was opened, coagulated blood almost occluded the right bronchus. Blood was also suctioned from the left main bronchus, but when all blood had been cleared away, it was apparent that the origin of the bleeding was from the right lung. We decided to evaluate only the left lung. After excision of the right lung, a $28 \mathrm{~F}$ venous cannula was placed with its tip in the proximal left pulmonary artery via the proximal part of the right pulmonary artery (Fig 2). The stump of the pulmonary trunk was oversewn. A baby feeding catheter was placed in the pulmonary artery to measure the perfusion pressure. The lung was placed in the assessment box and the perfusion was started (Fig 3). 


\section{The ex vivo equipment}

This equipment has been described in detail elsewhere (1-3). The system was primed with $2 \mathrm{~L}$ of Steen Solution ${ }^{\circledR}$ (Vitrolife AB, Kungsbacka, Sweden) mixed with erythrocytes (leucocyte filtered, irradiated) to a hematocrit of $16 \%$. Insulin 20IE (Actrapid; Nordisk Novo, Malmö, Sweden) and Imepenin $0.5 \mathrm{~g}$ (Tienam; MSD, Sollentuna, Sweden) were added to the solution that was buffered with Addex-THAM (Fresenius Kabi, Uppsala, Sweden) to a pH of 7.40. The gases used for the oxygenator incorporated into the system are $\mathrm{O}_{2}, \mathrm{CO}_{2}$ and $\mathrm{N}_{2}$. The oxygenated and normocapnic solution is circulated continuously in the system with the help of a shunt. Standard components for extra corporeal circulation can be used. We used a sterile "ready to use" kit prepared by Medtronic according to our instructions (Lung evaluation Ex-vivo kit, M460127C, Medtronic, Kerkrade, The Netherlands).

\section{$\underline{\text { Initial perfusion and reconditioning }}$}

After de-airing the pulmonary artery, a slow perfusion $(100 \mathrm{~mL} / \mathrm{min})$ was started at $25^{\circ} \mathrm{C}$. The gases $\mathrm{O}_{2}, \mathrm{CO}_{2}$, and $\mathrm{N}_{2}$ are mixed to get perfusate gas values of $\mathrm{PO}_{2} \approx 15 \mathrm{kPa}$ and $\mathrm{PCO}_{2} \approx 5$ $\mathrm{kPa}$. All blood gas values were corrected for the actual temperature. The temperature of the perfusate from the lung was continuously registered and the temperature of the ingoing perfusate was kept $10^{\circ} \mathrm{C}$ higher, up to a maximum temperature of $37^{\circ} \mathrm{C}$. The pressure in the pulmonary artery was never allowed to be higher than $20 \mathrm{mmHg}$.

When the temperature of the perfusate from the lung was $32^{\circ} \mathrm{C}$, ventilation $\left(1 \mathrm{~L} / \mathrm{min}, \mathrm{FiO}_{2}=\right.$ 0.50) was started. The perfusate flow and the minute ventilation were gradually increased. After 20 minutes, the lung was normothermic. The PEEP was kept at $5 \mathrm{cmH}_{2} \mathrm{O}$, except when it was 
increased temporarily to $10 \mathrm{cmH}_{2} \mathrm{O}$ to remove lower lobe atelectasis. After 30 minutes the ventilation was fixed at $3.5 \mathrm{~L} / \mathrm{min}$ (i.e., half of $100 \mathrm{~mL} / \mathrm{kg}$, the estimated optimum for two lungs, 12 breaths $/ \mathrm{min})$ and the perfusion flow fixed at $2.5 \mathrm{~L} / \mathrm{min}(\approx$ half of $70 \mathrm{~mL} / \mathrm{kg})$. At this perfusion flow, the pressure in the pulmonary artery was initially $12 \mathrm{mmHg}$, but after 50 minutes it had stabilized at $7 \mathrm{mmHg}$.

\section{$\underline{\text { The assessment }}$}

The gas mixture to the oxygenator was now shifted to $7 \% \mathrm{CO}_{2}$ and $93 \% \mathrm{~N}_{2}$. (AGA Gas $\mathrm{AB}$, Sundbyberg, Sweden). Blood gases of the perfusate were taken before and after passing through the lung after 10 minutes exposure of $\mathrm{FiO}_{2}$ of $0.5,1.0$ and 0.21 , respectively. The blood gas values obtained are shown in table 1. After completion of the blood gas testing, a collapse test was done. This consists of observing the lung after a sudden disconnection of the endotracheal tube from the ventilator. In a normal lung the whole lung should collapse (global atelectasis). We deemed the result of the collapse test to be normal. The lung was judged acceptable for transplantation and a decision to transplant it was made.

\section{Topical ECMO until transplantation the next day}

The temperature of the ingoing perfusate was reduced to $25^{\circ} \mathrm{C}$ and when that temperature was reached in the perfusate coming from the lung, the perfusion was stopped. The pulmonary artery cannula and the trachea were clamped with the lung in a semi-inflated state $\left(\mathrm{FiO}_{2}=1.0\right)$ after which it was immersed in the perfusate diluted with buffered Perfadex ${ }^{\circledR}$. The gases to the oxygenator was now set similar as during the initial perfusion and reconditioning. The temperature of the solution was kept at $8^{\circ} \mathrm{C}$ and the solution was run through the oxygenator ( 2 
$\mathrm{L} / \mathrm{min}$ ) so that an oxygenated and normocapnic solution surrounded the lung tissue at all times. This procedure, topical ECMO (extra corporeal membrane oxygenation), kept the lung semiinflated throughout the storage period, i.e., during the night. The recipient operation was started the next morning (Table 2).

\section{$\underline{\text { The recipicent }}$}

The recipient was called from abroad and arrived with an ordinary airflight. He was a 70-yearold man (height: $170 \mathrm{~cm}$, body weight $56 \mathrm{~kg}$, blood group A Rhesus positive) with COPD who had been on 24-hour oxygen therapy for the last 10 years. Due to old age, he was not considered a candidate for lung transplantation in his home country. He had signed a document stating that he would agree to be transplanted with a nonacceptable donor lung if a successful reconditioning could be done. He had been examined 2 months earlier in our hospital, and no contraindication for lung transplantation was found. His $\mathrm{FEV}_{1}$ was less than $20 \%$ of predicted during the last year. During the last month, his health had severely deteriorated, and he had almost lost hope of recieving a new lung.

\section{The transplantation}

The recipient was intubated with a Carlen's double-lumen tube (Rüsch, Kernen, Germany) and a posterolateral left-sided thoracotomy was done through the $5^{\text {th }}$ intercostal space. The pulmectomy and implantation of the donor lung were performed without difficulties

Reperfusion of the lung was started at 10 am, 17 hours after the harvesting procedure. The transplanted lung functioned properly immediately after reperfusion, and the patient produced 
normal blood gases 10 minutes after reperfusion with $\mathrm{FiO}_{2}=0.3$. The size of the donor lung filled up the thoracic cavity well and there was no problem in closing the thoracotomy.

\section{RESULTS}

\section{The postoperative course}

The patient received immunosuppression according to our routines (ATG x3, cyclosporine A, azathioprine, and prednisolone). He was extubated in the afternoon 4 hours after arrival into the intensive care unit and transferred to an ordinary ward the next day. After one week he required no supplementary oxygen. After 4 weeks he was healthy enough for a sight-seeing tour in Southern Sweden with his wife. During the 6-week period he was under observation by us, no rejection incidents occurred. His chest X-ray was normal (Fig 4) and he left for his home country 6 weeks after the transplantation in a very good condition.

\section{Follow up}

Seven weeks after the transplantation, the patient was found to be CMV-PCR positive and treatment with Cymvene was started. Three months after the transplantation, the following status was documented by the responsible doctor at home: Good general condition. Blood pressure 120/70. Cyclosporine in serum 200-150 $\mu \mathrm{g} / \mathrm{L}$. Creatinine $91 \mu \mathrm{mol} / \mathrm{L}$. Liver tests normal. CRP $9 \mathrm{mg} / \mathrm{L}$. Cholesterol $4.7 \mathrm{mmol} / \mathrm{L}$. GFR $68 \mathrm{~mL} / \mathrm{min}$ ( $85 \%$ of predicted value). CT thorax shows normal transplanted left lung and emphysema of the right lung. Rigid bronchoscopy with transbronchial biopsies showed no sign of rejection. Spirometry: FVC 2.69 L (74\% of predicted), $\mathrm{FEV}_{1} 1.73 \mathrm{~L}(62 \%)$, DLCO 5.8 (70\%), KCO 1.33 (105\%), 6-minute walking test without oxygen $495 \mathrm{~m}$, pulse oximetric saturation measurement during walking test 
95 to $97 \%$, arterial blood gas (without oxygen), $\mathrm{pH} 7.47, \mathrm{PCO}_{2} 4.8 \mathrm{kPa}, \mathrm{PO}_{2} 9.7 \mathrm{kPa}$. CMVPCR was negative in two tests. Conclusion: "Very satisfactory condition". Cymvene treatment stopped, Valcyte $900 \mathrm{mg}$ x 1 ordered for 4 weeks. Immunosuppressive treatment: cyclosporine (Sandimun) $100 \mathrm{mg} \mathrm{x} \mathrm{2,} \mathrm{azathioprine} \mathrm{(Imurel)} 50 \mathrm{mg} \mathrm{x} \mathrm{1,} \mathrm{prednisolone} 10 \mathrm{mg} \times 1$ (soon to be reduced).

Eight months after the transplantation the patient was diagnosed with EBV-positive large cell lymphoma in the transplanted lung. He received 4 CHOP chemotherapy treatments and the tumor disappeared. On the $30^{\text {th }}$ of March 2006, Professor Steen received an enthusiastic letter from the patient who was participating intensively in all kinds of social life activities together with his wife. They were planning to come to Lund for a 1-year check-up at the end of May 2006. The only medical problem now was leucopenia after the CHOP treatments. One month later the patient got acute sepsis and died.

\section{COMMENT}

Of paramount importance is the history of the potential donor and, if available, the arterial blood gases during the final hours before and after brain death. If the blood gases have been acceptable for donation initially, but have deteriorated during the last hours before the donation operation, this is positive information to consider together with the results from the ex vivo evaluation. The macroscopic inspection and palpation of the lungs ex vivo before and after a collapse test, ie, disconnecting the lung from the ventilator and allowing it to collapse, gives important information regarding lung compliance and the presence or absence of pulmonary edema. Bronchoscopy should be done during the ex vivo evaluation period if part of the lung does not 
collapse, to exclude mucous stagnation or other causes of an obstructed bronchus. If deemed necessary, an X-ray should be done. A most reliable blood gas is that obtained with a $\mathrm{FiO}_{2}$ of 0.21. $\mathrm{A} \mathrm{PaO}_{2}$-value less than $8 \mathrm{kPa}(60 \mathrm{mmHg})$ is a sign of a clinically significant impairment in oxygen exchange capacity. The minimum perfusion flow we use is $70 \mathrm{~mL} / \mathrm{kg}$ body weight of the donor, ie, $4.9 \mathrm{~L} / \mathrm{min}$ according to the donor weight in this report. Since only the left lung was evaluated, half of that flow $(2.5 \mathrm{~L} / \mathrm{min})$ was used. The mean pulmonary artery pressure at that flow should be less than $20 \mathrm{mmHg}$. In the present case it was initially $12 \mathrm{mmHg}$, falling to 7 $\mathrm{mmHg}$, indicating a favorable low pulmonary vascular resistance. For more detailed considerations regarding ex vivo evaluation of lungs, see references 1-3.

Other investigators have reported favorable experimental results regarding ex vivo evaluation of lungs (4-7). The present patient is the first to be transplanted with a nonacceptable donor lung after successful reconditioning ex vivo.

Since this case, we have done 4 double-single and 1 single lung transplantations using nonacceptable donor lungs that have been successfully reconditioned ex vivo, and all patients are doing well. Long-term follow-up of a larger material is necessary before this method may become clinical routine. 
Recondition of nonacceptable donor lung

\section{ACKNOWLEDGEMENTS}

We want to thank the nurses Ann-Christin Nilsson, Evamarie Braf, Camilla Olin and Birgit Malmros for their skillful help and enthusiastic support before, during and after the transplantation. The project was supported by grants from the Swedish Heart Lung Foundation and Lund University Hospital. 
Recondition of nonacceptable donor lung

\section{REFERENCES}

1. Steen S, Liao Q, Wierup P, Bolys R, Pierre L, Sjöberg T. Transplantation of lungs from non-heart-beating donors after functional assessment ex vivo. Ann Thorac Surg $2003 ; 76: 244-252$.

2. Steen S, Sjöberg T, Pierre L, Liao Q, Eriksson L, Algotsson L. Transplantation of lungs from a non-heart-beating donor. Lancet 2001;357:825-829.

3. Wierup P, Haraldsson Å, Nilsson F, et al. Ex vivo evaluation of nonaccepatble donor lungs. Ann Thorac Surg 2006;81:460-466.

4. Van Raemdonk DEM, Rega FR, Neyrinck AP, et al. Non-heart-beating donors. Semin Thorac Cardiovasc Surg 2004;16:309-321.

5. Erasmus ME, Fernhout MH, Elstrodt JM, Rakhorst G. Normothermic ex vivo lung perfusion of non-heart-beating donor lungs in pigs: from pretransplant function analysis towards a 6-h machine preservation. Transplant International 2006;19:589593.

6. Snell GI, Oto T, Levvey B, et al. Evaluation of techniques for lung transplantation following donation after cardiac death. Ann Thorac Surg 2006; 81:2014-2019.

7. Egan TM, Haithcock JA, Nicotra WA, et al. Ex vivo evaluation of human lungs for transplant suitability. Ann Thor Surg 2006;81:1205-1213. 
Table 1.

Hemodynamic and gas exchange function after reconditioning of the left donor lung.

\begin{tabular}{|c|c|c|c|}
\hline & \multicolumn{3}{|c|}{ Inspired oxygen fraction } \\
\hline & 0.5 & 1.00 & 0.21 \\
\hline Perfusate hematocrit (\%) & 16 & 16 & \\
\hline & & & \\
\hline Perfusate temperature $\left({ }^{\circ} \mathrm{C}\right)$ & 37 & 37 & 37 \\
\hline Perfusate flow (L/min) & 2.5 & 2.5 & 2.5 \\
\hline Ventilation flow (L/min) & 3.5 & 3.5 & 3.5 \\
\hline MPAP $(\mathrm{mmHg})$ & 7 & 7 & 7 \\
\hline LAP (mmHg) & 0 & 0 & 0 \\
\hline PVR (dynes x s x cm ${ }^{-5}$ ) & 224 & 224 & 224 \\
\hline $\mathrm{pHv}$ & 7.38 & 7.42 & 7.41 \\
\hline $\mathrm{PvCO}_{2}(\mathrm{kPa})$ & 6.08 & 6.12 & 6.04 \\
\hline $\mathrm{PvO}_{2}(\mathrm{kPa})$ & 4.53 & 4.90 & 4.03 \\
\hline $\mathrm{SvO}_{2}(\%)$ & 83 & 85 & 82 \\
\hline $\mathrm{pHa}$ & 7.43 & 7.47 & 7.46 \\
\hline $\mathrm{PaCO}_{2}(\mathrm{kPa})$ & 5.08 & 5.29 & 5.12 \\
\hline $\mathrm{ETCO}_{2}(\mathrm{kPa})$ & 4.3 & 4.6 & 4.4 \\
\hline $\mathrm{PaO}_{2}(\mathrm{kPa})$ & 32.1 & 52.2 & 14.0 \\
\hline $\mathrm{SaO}_{2}(\%)$ & 100 & 100 & 100 \\
\hline
\end{tabular}

Minute perfusate flow for one lung: $35 \mathrm{~mL} / \mathrm{kg}$ body weight of the donor. Minute ventilation one lung: $50 \mathrm{~mL} / \mathrm{kg}$ body weight of donor, 12 breaths $/ \mathrm{min}$, PEEP $5 \mathrm{cmH}_{2} \mathrm{O} . \mathrm{MPAP}=$ mean pulmonary arterial pressure, $\mathrm{LAP}=$ left atrial pressure, $\mathrm{PVR}=$ pulmonary vascular resistance, 
Recondition of nonacceptable donor lung

$\mathrm{pHv}=$ venous blood $\mathrm{pH}, \mathrm{PvCO}_{2}=$ partial pressure venous blood carbon dioxide, $\mathrm{PvO}_{2}=$ partial pressure venous blood oxygen, $\mathrm{SvO}_{2}=$ oxygen saturation of venous blood, $\mathrm{pHa}=$ arterial blood $\mathrm{pH}, \mathrm{PaCO}_{2}=$ partial pressure arterial blood carbon dioxide, $\mathrm{PaO}_{2}=$ partial pressure arterial blood oxygen, $\mathrm{SaO}_{2}=$ oxygen saturation of arterial blood. $1 \mathrm{kPa}=7.5 \mathrm{mmHg}$. 
Table 2.

Schedule for the operation

\begin{tabular}{|l|l|l|}
\hline & Time & Event \\
\hline Day 1 & $5 \mathrm{pm}$ & Harvesting of donor lungs. Preservation with Perfadex ${ }^{\circledR}$. \\
\hline & $5 \mathrm{pm}$ to $10 \mathrm{pm}$ & Cold ischemic storage in Perfadex ${ }^{\circledR}(5 \mathrm{~h})$ \\
\hline & $10 \mathrm{pm}$ to $11.30 \mathrm{pm}$ & Evaluation and reconditioning ex vivo $(1.5 \mathrm{~h})$ \\
\hline & $11.30 \mathrm{pm}$ & Start of topical ECMO at $8^{\circ} \mathrm{C}$ \\
\hline Day 2 & $8.30 \mathrm{am}$ & Cessation of topical ECMO $(9 \mathrm{~h})$ \\
\hline & $10 \mathrm{am}$ & Reperfusion of the transplanted lung $(17 \mathrm{~h}$ after harvest $)$ \\
\hline & $4 \mathrm{pm}$ & Extubation of patient \\
\hline
\end{tabular}


Recondition of nonacceptable donor lung

\section{LEGEND TO FIGURES}

Fig 1. Inspection of the donor lungs. A large hematoma is seen in the right lung. Small bleeding spots are seen on the lower lobe of the left lung. No hematoma could be palpated in the left lung.

Fig 2. Schematic drawing of the left donor lung ready for ex vivo assessment.

1. Endotracheal tube fixed in trachea. 2. The pulmonary artery trunk closed with a suture. 3. Baby feeding catheter in the left pulmonary artery for pressure measurement. 4. Left pulmonary artery cannulated via the stump of the right pulmonary artery. 5. Cuff of left atrium containing the left pulmonary veins.

Fig 3. Ex vivo reconditioning of the left lung. The perfusate from the lung goes into a sterile plastic box and from there to the venous reservoir. For the sake of clarity, the top of the box is lifted off.

Fig 4. Chest X-ray ten days after left lung transplantation. 
$11 \div$

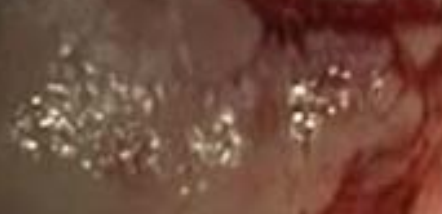

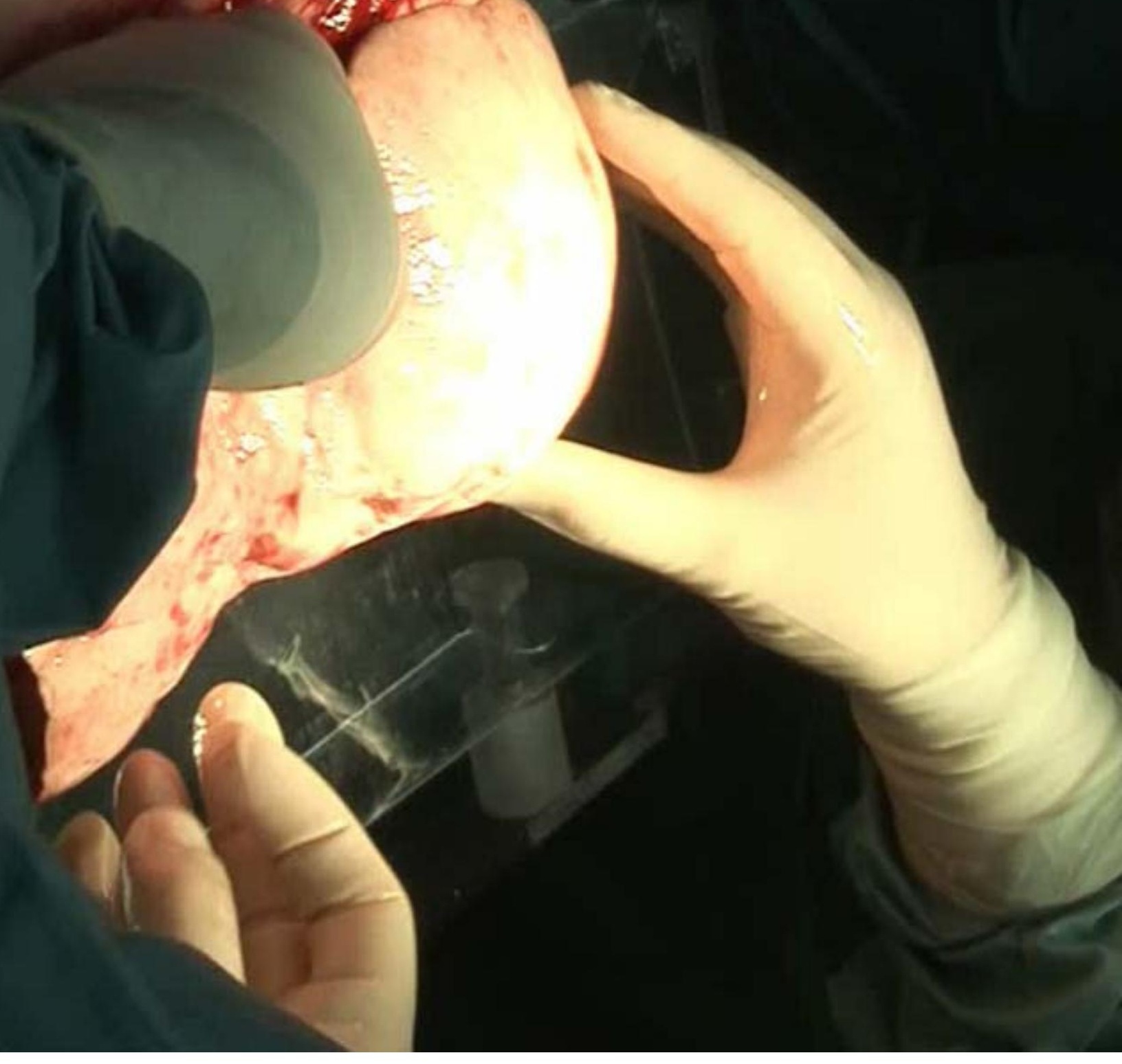

Figure 1 


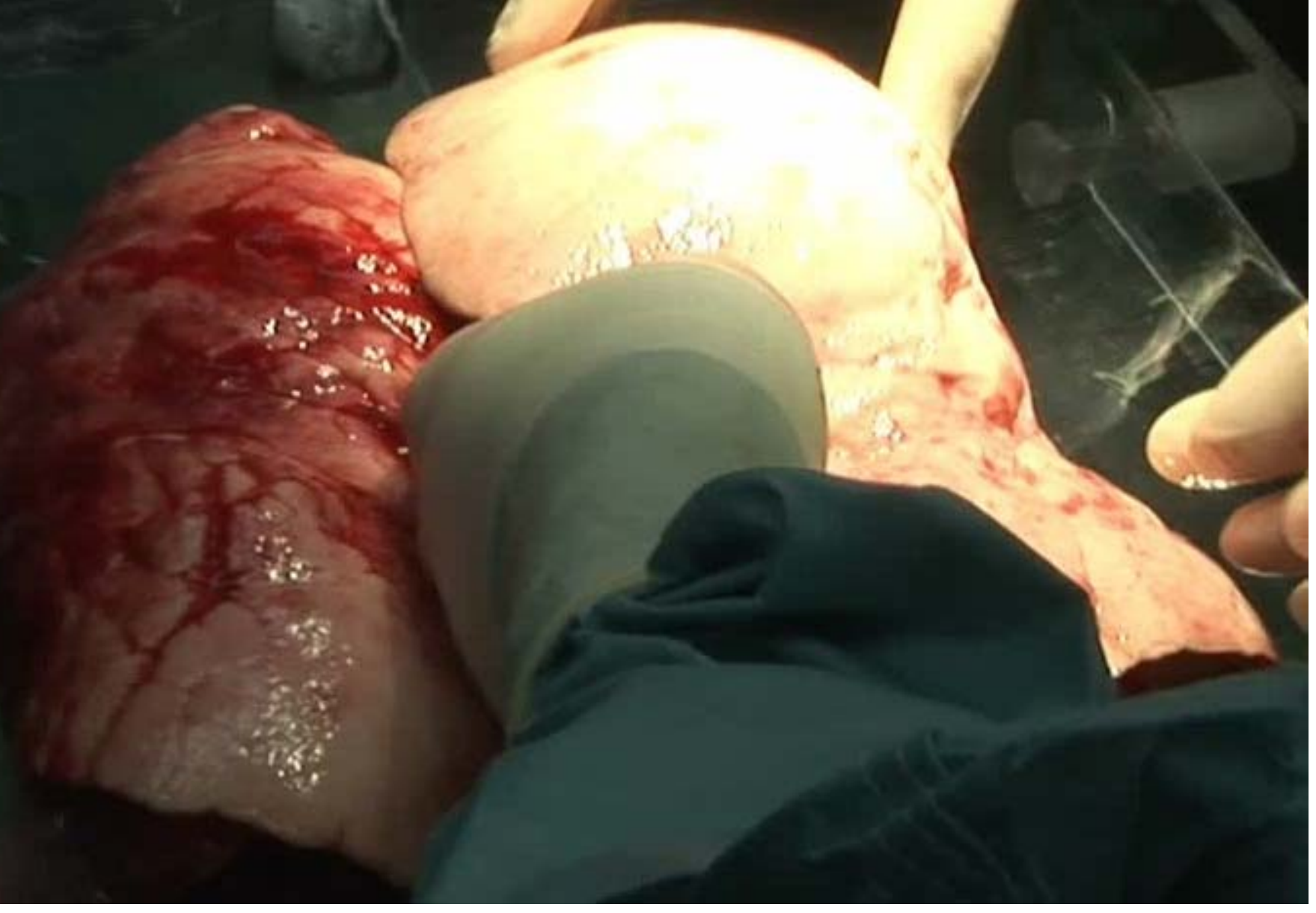

Figure 1b 
Figure 2 

